\title{
The role of the clinical and psychological symptoms of mastocytosis in the patient's quality of life
}

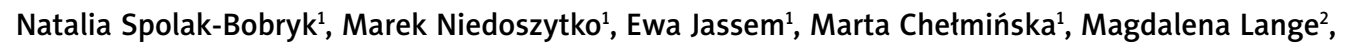 \\ Mikołaj Majkowicz ${ }^{3}$, Bogusław Nedoszytko², Judyta Borchet ${ }^{4}$ \\ ${ }^{1}$ Department of Allergology, Medical University of Gdansk, Gdansk, Poland \\ ${ }^{2}$ Department and Clinic of Dermatology, Venereology and Allergology, Medical University of Gdansk, Gdansk, Poland \\ ${ }^{3}$ Faculty of Health Sciences, Pomeranian University, Slupsk, Poland \\ ${ }^{4}$ Division of Research on Family and Quality of Life, Institute of Psychology, University of Gdansk, Gdansk, Poland \\ Adv Dermatol Allergol 2022; XXXIX (4): 688-696 \\ DOI: https://doi.org/10.5114/ada.2021.108433
}

\begin{abstract}
Introduction: Patients with mastocytosis have various clinical and psychological symptoms, for example, life-threatening anaphylactic reactions or anxiety, resulting in decreased quality of life (QoL).

Aim: To assess the clinical and psychological symptoms (such as depression, anxiety) as well as the quality of life and satisfaction with life in patients with mastocytosis.

Material and methods: The study group included 85 patients with mastocytosis ( 57 women and 28 men) treated at the Department of Allergology, Medical University of Gdansk, Poland. The measures employed in the study were the following: HADS-M, QLMS, and Cantril ladder.

Results: Among clinical symptoms that occurred in the studied group, only allergy differentiated between the patients in terms of their QoL. Patients experiencing allergy symptoms presented lower QoL in the area of leisure time. The study findings indicate that $27.1 \%$ of participants experience anxiety, $12.9 \%$ experience depression, $15.3 \%$ present low satisfaction with the current life, and $10.6 \%$ express low satisfaction with life in the next 4 weeks. General QoL in mastocytosis, as well as the four areas of QoL in mastocytosis, remain positively correlated with anxiety, depression, and irritability, as well as negatively correlated with the satisfaction with current life and life in 4 weeks' time.

Conclusions: Patients who experience allergy symptoms have a lower level of QoL in the area of leisure time. Having more obstacles in various areas of life is associated with anxiety, depression, irritability, and low satisfaction with life. Learning how to overcome them can potentially improve the patients' QoL.
\end{abstract}

Key words: mastocytosis, quality of life, clinical symptoms, psychological symptoms.

\section{Introduction}

Mastocytosis is a rare heterogeneous neoplastic disease characterized by excessive, pathological accumulation of mast cells in one or more organs and release of their mediators. The disease is estimated to occur in approximately 10 per 100,000 people and is classified as a haematological neoplasm [1-3]. Mastocytosis has a wide spectrum of clinical manifestations: when the pathological accumulation of mast cells is limited only to the skin, the cutaneous mastocytosis (CM) is diagnosed, whereas when the accumulation of mast cells occurs in internal organs (most commonly the skin, bone marrow, gastrointestinal tract, spleen, liver and lymph nodes), the systemic mastocytosis (SM) is diagnosed. The clinical spectrum of mastocytosis also includes rare, unifocal mast cell tumours such as mast cell sarcoma, a poorly differentiated neoplasm that grows with the destruction of the surrounding tissue. The World Health Organisation (WHO) classification of the clinical forms of mastocytosis is shown in Figure $1[4,5]$.

The cutaneous form of mastocytosis appears in early childhood. It is manifested by urticaria pigmentosa (reddish-brown skin lesions), but the occurrence of Darier's sign is also possible (nodules, papules or blisters, which cause redness and swelling when stroked), which is

Address for correspondence: Natalia Spolak-Bobryk, Department of Allergology, Medical University of Gdansk, Gdansk, Poland, e-mail: natalia.spolak@gumed.edu.pl Received: 17.04.2021, accepted: 29.05.2021. 
caused by the mediators contained in the inflammatory granules released by the mast cells.

In the systemic form of mastocytosis, mast cells usually accumulate in the bone marrow, spleen, liver, gastrointestinal tract, and lymph nodes. The infiltration of tissues by mast cells carries the risk of organ dysfunction and eventually the occurrence of significant disorders, such as impairment of the bone marrow function, liver failure, or osteoporotic fractures. The most common mediator-dependent symptoms include abdominal pain, fainting, diarrhoea, flushing (paroxysmal erythema), tachycardia, skin pruritus, dizziness and headache, nausea, fatigue, hypotonia, hypotension, and anaphylactic shock.

Mastocytosis can also be asymptomatic, but the dysfunction of the organism can be diagnosed on the basis of abnormalities in peripheral blood cell count, i.e., anaemia (too few erythrocytes), thrombocytopenia (decreased platelet count) or leukopenia (too few white blood cells) [3, 5-9]. Mastocytosis, both cutaneous and systemic, is associated with a risk of anaphylactic reaction. It occurs in about $50 \%$ of adults and about $5-10 \%$ of children with mastocytosis. In adults, it is usually related to an allergy to Hymenoptera venom, and in most children, it is provoked by an unknown factor [6]. Importantly, systemic mastocytosis is often accompanied by skin involvement, with typical skin lesions occurring in about $80 \%$ of all patients with mastocytosis.

Diagnosis of mastocytosis is based on histopathological examination of the skin and bone marrow, determination of serum tryptase levels, bone marrow cytology, immunophenotyping and detection of D816V mutation in the KIT gene. The main aim of the treatment of patients with indolent systemic and cutaneous mastocytosis is to prevent or reduce the severity of symptoms. The treatment is primarily based on patient education, the recommendation to avoid agents that provoke mast cell degranulation, the alleviation of acute and chronic mediator-related symptoms with antihistamine drugs blocking $\mathrm{H} 1$ and $\mathrm{H} 2$ receptor, cromones, leukotriene receptor antagonists, oral steroids, omalizumab, along with chemotherapy lesions in aggressive mastocytosis, and bone marrow transplantation in the most severe cases [5].

Patient education is closely linked to the information on factors that may lead to exacerbation of mastocytosis symptoms and anaphylactic reactions, such as exposure to sudden temperature changes, certain foods, additives or preservatives, pungent spices, some drugs, various allergens, sunlight, alcohol, venoms (hymenopterous insects, jellyfish, snakes), latex, physical exertion, stress, bacterial and viral infections, mechanical irritation of skin lesions, fever or invasive diagnostic and therapeutic procedures. Mastocytosis patients or their caregivers should be trained in first aid in the event of an anaphylactic shock [1, 10-13].

\begin{tabular}{|c|l|}
\cline { 2 - 2 } \multicolumn{1}{c|}{$\begin{array}{c}\text { Cutaneous } \\
\text { mastocytosis (CM) }\end{array}$} & $\begin{array}{l}\text { - Maculopapular CM (MPCM) = urticaria } \\
\text { pigmentosa (UP) } \\
\text { - Diffuse CM (DCM) } \\
\text { - Mastocytoma of skin }\end{array}$ \\
\hline \begin{tabular}{|l|l|} 
Systemic mastocytosis \\
(SM)
\end{tabular} & $\begin{array}{l}\text { - Indolent SM (ISM) } \\
\text { - Smoldering SM (SSM) } \\
\text { - SM with associated hematologic } \\
\text { neoplasm (AHN)a } \\
\text { - Aggressive SM (ASM) } \\
\text { - Mast cell leukemia (MCL) }\end{array}$ \\
\hline Mast cell sarcoma \\
(MCS)
\end{tabular}

Figure 1. Classification of mastocytosis: current status and outlook toward the future (Valent et al. Cancer Res 2017)

The variety of forms of mastocytosis poses a significant problem as it impairs the diagnosis and treatment. This can cause further psychological problems, such as confusion, helplessness, and a sense of threat [14]. As many as $73 \%$ of patients experience anxiety due to the disease. Its principal causes include a long time to diagnosis (a mean of nearly 7 years), variety of forms, uncontrollable symptoms, inability to lead an active professional and social life (sense of exclusion, isolation, feeling useless), pain, chronic fatigue, disfigurement (skin lesions), fear of biopsy and chemotherapy [15, 16]. The anxiety experienced by patients may be associated with the sense of threat (unfavourable prognosis, threat to life), with symptoms (nausea, vomiting), and with the diagnostic and therapeutic procedures (radiotherapy, chemotherapy, biopsy). The increased anxiety is a result of disturbed cognitive functions (memory disorders, inability to concentrate), and disability (loss of autonomy and/or dependence on other people) [17].

\section{Aim}

The aim of the study was to assess the clinical and psychological symptoms (such as depression, anxiety) as well as the quality of life and satisfaction with life in patients with mastocytosis.

\section{Material and methods}

Eighty five patients participated in the study (57 women and 28 men) aged from 18 to $77\left(M_{\text {total }}=46.22, \mathrm{SD}_{\text {total }}=\right.$ $13.10 ; M_{\text {men }}=43.32, S_{\text {men }}=10.80, M_{\text {women }}=46.67, S_{\text {women }}$ $=14.16 ; Z=-0.64, p<0.05)$. All of them had mastocytosis and were treated at the Department of Allergology, Medical University of Gdansk (Poland). The participants were diversified by their educational status, with higher education being the most prevalent (55.3\%). Other participants had either secondary (27.1\%), vocational (12.9\%), or primary education (4.7\%). The participants' relationship status was as follows: married (75.3\%), single (18.9\%), widowed 
(3.5\%), and divorced (2.4\%). Most of the participants were employed (71.8\%). Some of them were retired or receiving a pension (18.9\%), while $9.4 \%$ were unemployed.

The study received approval from the Independent Bioethics Committee for Scientific Research at the Medical University of Gdansk (NKBBN/550/2015). Participation in the study was voluntary and anonymous. The patients were invited to join the study by psychologists while they were visiting the clinic. None of them denied the request. All patients signed informed consent prior to joining the study. The study protocol lasted approximately 30 to 40 min. The data collection started in 2015 and was completed in 2019.

Using the psychological tools listed below, the level of anxiety and depression, as well as the level of satisfaction and quality of life were analysed in the study participants. The following questionnaires were used: HADS-M, Cantril Ladder, and Quality of Life in Mastocytosis Scale (QLMS).

Hospital Anxiety and Depression Scale - Modified Version (HADS-M) was created by Zigmond and Snaith. The version employed in this study was adapted for use in Poland by Majkowicz, de Walden-Gałuszko and ChojnackaSzawłowska [18]. HADS-M includes three subscales: depression (HADS-D), anxiety (HADS-A), and irritability. The scale allows assessing the presence of these symptoms in patients hospitalized due to somatic causes. The scale includes 16 statements, assessed on a 4-point scale (i.e., 1 = definitely yes, 2 = rather yes, 3 = rather no, $4=$ definitely no). The possible scores range from 0 to 21 points. Scores from 0 to 7 are considered normal, from 8 to 10 are borderline, those above 11 signify a high level of anxiety and/or depression in the setting of a hospital outpatient clinic [19].

Cantril Ladder is a visual measure of life satisfaction. It is presented in the form of a ladder, whose steps are marked with consecutive numbers from 0 to 10 . The top step, numbered 10, means the best possible life, while the bottom step, numbered 0 , implies the worst possible life. The respondent evaluates his or her life (1) at the current moment and (2) predicts his or her satisfaction with life in the next 4 weeks by marking the right step of the ladder [20]. Scores lower than 6 indicate people unsatisfied with their lives while scores above 6 are considered as an indicator of being satisfied with one's life.

Quality of Life in Mastocytosis Scale (QLMS) is a mastocytosis-specific quality of life measure. It assesses the quality of patients' lives in four domains such as leisure time, protective behaviours, professional life, and life limitations. The scale includes 24 items with a score ranging from 0 (there are no limitations in a given area) to 5 points (the limitation prevents normal functioning). Raw scores are summed and then divided by the number of items on each subscale. The higher the score in a given subscale, the more difficulties the patient experiences in that area of life. The scale also provides a total score expressed as the mean score of all the items [21].

\section{Statistical analysis}

The analyses were performed using IBM SPSS Statistics 23. Data on continuous variables (i.e., age, Cantril ladder scores, HADS-M, and QLMS subscales' scores) were presented as means and standard derivations (SD) (Table 1). To test whether gender or mastocytosis type differentiate between the patients in terms of their subscales' scores, and taking into consideration that the groups were unequal, the non-parametric U Mann-Whitney tests were performed [22, 23]. The results are presented in Tables 2 and 3, respectively, alongside with medians and quartiles. Values of $p<0.05$ were considered statistically significant. As all of the differences were non-significant, gender was not included in further analysis. Moreover, the mastocytosis type (i.e., cutaneous or systemic) did not significantly differ between the patients in terms of their general quality of life and its domains as measured by QLMS (Table 3).

Table 1. General descriptive statistics $(N=85)$

\begin{tabular}{|c|c|c|c|c|}
\hline Variable & Min. & Max. & Mean & SD \\
\hline Age & 18 & 77 & 46.22 & 13.10 \\
\hline HADS-M Anxiety & 0.0 & 17.0 & 5.47 & 4.06 \\
\hline HADS-M Depression & 0.0 & 9.0 & 2.99 & 2.94 \\
\hline HADS-M Irritability & 0 & 6 & 2.59 & 1.58 \\
\hline Cantril - today & 7.39 & 1.59 & 3.0 & 10.0 \\
\hline Cantril - next 4 weeks & 7.80 & 1.51 & 4.0 & 10.0 \\
\hline QLMS - leisure time & 0.00 & 4.44 & 0.55 & 0.77 \\
\hline QLMS - protective behaviours & 0.00 & 4.33 & 0.51 & 0.76 \\
\hline QLMS - professional life & 0.00 & 4.75 & 0.62 & 0.98 \\
\hline QLMS - life limitations & 0.00 & 5.00 & 0.89 & 1.07 \\
\hline QLMS - global quality of life in mastocytosis & 0.00 & 4.63 & 0.64 & 0.80 \\
\hline
\end{tabular}


Table 2. Gender differences in questionnaires' results

\begin{tabular}{|c|c|c|c|c|c|c|c|c|c|}
\hline \multirow[t]{2}{*}{ Variable } & \multirow{2}{*}{$\begin{array}{l}\text { Mean rank } \\
- \text { men }\end{array}$} & \multicolumn{3}{|c|}{ Quartiles - men } & \multirow{2}{*}{$\begin{array}{l}\text { Mean rank } \\
\text { - women }\end{array}$} & \multicolumn{3}{|c|}{ Quartiles - women } & \multirow{2}{*}{$\begin{array}{l}\text { U-Mann Whitney } \\
\text { test of group } \\
\text { differences }\end{array}$} \\
\hline & & $25^{\text {th }}$ & $50^{\text {th }}$ & $75^{\text {th }}$ & & $25^{\text {th }}$ & $50^{\text {th }}$ & $75^{\text {th }}$ & \\
\hline HADS-M Anxiety & 37.14 & 1.00 & 4.00 & 7.75 & 45.88 & 3.00 & 4.00 & 9.00 & -1.54; n.s. \\
\hline HADS-M Depression & 46.66 & 0.25 & 2.50 & 6.50 & 41.20 & 0.00 & 2.00 & 5.00 & $-0.97 ;$ n.s. \\
\hline HADS-M Irritability & 40.36 & 1.25 & 2.50 & 3.00 & 44.30 & 1.50 & 3.00 & 4.00 & $-0.71 ;$ n.s. \\
\hline Cantril - today & 45.63 & 7.00 & 8.00 & 8.00 & 41.71 & 6.00 & 8.00 & 8.00 & $-0.71 ;$ n.s. \\
\hline Cantril - next 4 weeks & 38.88 & 7.00 & 8.00 & 8.00 & 45.03 & 7.00 & 8.00 & 9.00 & $-1.11 ;$ n.s. \\
\hline QLMS - leisure time & 39.27 & 0.00 & 0.17 & 0.92 & 44.83 & 0.00 & 0.44 & 0.89 & $-1.01 ;$ n.s. \\
\hline QLMS - protective behaviours & 38.54 & 0.00 & 0.00 & 0.67 & 45.19 & 0.00 & 0.33 & 0.83 & -1.24; n.s. \\
\hline QLMS - professional life & 43.57 & 0.00 & 0.38 & 0.94 & 42.72 & 0.00 & 0.00 & 1.00 & $-0.16 ;$ n.s. \\
\hline QLMS - life limitations & 39.96 & 0.00 & 0.50 & 1.15 & 44.49 & 0.00 & 0.60 & 1.30 & $-0.81 ;$ n.s. \\
\hline $\begin{array}{l}\text { QLMS - global quality of life in } \\
\text { mastocytosis }\end{array}$ & 40.14 & 0.01 & 0.44 & 0.78 & 44.40 & 0.18 & 0.39 & 0.99 & $-0.75 ;$ n.s. \\
\hline
\end{tabular}

Table 3. Quality of life in cutaneous and systemic mastocytosis patients $(n=85)$

\begin{tabular}{|c|c|c|c|c|c|c|c|c|c|}
\hline \multirow[t]{3}{*}{ Variable } & \multicolumn{4}{|c|}{ Cutaneous mastocytosis $(n=19)$} & \multicolumn{4}{|c|}{ Systemic mastocytosis $(n=66)$} & \multirow{3}{*}{$\begin{array}{c}\text { U-Mann } \\
\text { Whitney test } \\
\text { of group } \\
\text { differences }\end{array}$} \\
\hline & \multirow{2}{*}{$\begin{array}{c}\text { Mean } \\
\text { rank }\end{array}$} & \multicolumn{3}{|c|}{ Quartiles } & \multirow{2}{*}{$\begin{array}{c}\text { Mean } \\
\text { rank }\end{array}$} & \multicolumn{3}{|c|}{ Quartiles } & \\
\hline & & $25^{\text {th }}$ & $50^{\text {th }}$ & $75^{\text {th }}$ & & $25^{\text {th }}$ & $50^{\text {th }}$ & $75^{\text {th }}$ & \\
\hline QLMS - leisure time & 47.97 & 0.00 & 0.44 & 1.11 & 41.57 & 0.00 & 0.28 & 0.78 & -1.03; n.s. \\
\hline QLMS - protective behaviours & 44.03 & 0.00 & 0.33 & 0.67 & 42.70 & 0.00 & 0.08 & 0.83 & $-0.22 ;$ n.s. \\
\hline QLMS - professional life & 39.37 & 0.00 & 0.00 & 0.50 & 44.05 & 0.00 & 0.25 & 1.00 & -0.78; n.s. \\
\hline QLMS - life limitations & 46.42 & 0.40 & 0.60 & 1.20 & 42.02 & 0.00 & 0.60 & 1.20 & $-0.70 ;$ n.s. \\
\hline $\begin{array}{l}\text { QLMS - global quality of life in } \\
\text { mastocytosis }\end{array}$ & 45.50 & 0.26 & 0.52 & 0.84 & 42.28 & 0.07 & 0.38 & 0.85 & $-0.50 ;$ n.s. \\
\hline
\end{tabular}

\section{Results}

There were 85 mastocytosis patients participating in the study (57 women and 28 men), treated at the Department of Allergology, Medical University of Gdansk, Gdansk, Poland. The descriptive data regarding the participant's gender, age, and mastocytosis type are presented in Table 4 below.

The frequencies of clinical symptoms occurrence in the studied group are presented in Table 5 below. None of the patients was found to experience malabsorption, portal hypertension, ascites, dysmyelopoiesis, and lymphadenopathy. $81.2 \%(n=69)$ of the participants did not provide any information on the occurrence of hypotension so this parameter was not analysed further. Also, the results of ANOVAs indicated that flushing and pruritus did not differentiate between the patients in terms of their quality of life or its domains $(p>0.05)$ and the level of tryptase was not correlated with the general quality of life in mastocytosis or with its four domains $(p>0.05)$.

The differences in the quality of life and its 4 domains (leisure time, protective behaviours, professional life, and life limitations) for two independent groups of patients with or without clinical symptoms such as: allergy, GI tract symptoms, osteopenia/osteoporosis symptoms, constitutional/cardiovascular symptoms, weight loss, and hepatomegaly, are presented in Table 6 below. Surprisingly, the occurrence of those symptoms did not affect the patients' quality of life, with only one exception. Patients who experienced allergy symptoms experienced more dissatisfaction with their leisure time than those who did not suffer from allergy symptoms.

The study findings indicate that $27.1 \%$ of study participants experienced anxiety, and $12.9 \%$ demonstrated signs of depression (i.e., HADS subscales scored higher than 7). Therefore, anxiety was more prevalent than depression. Low satisfaction with the current life was experienced by $15.3 \%$ of the patients and the satisfaction with life in the next 4 weeks was assessed as low by $10.6 \%$ of study participants (i.e., scores on Cantril ladder lower than 6). None of the patients presented borderline or high levels of irritability.

The effect sizes varied from low to moderate (rho coefficients ranging from 0.23 to 0.47 ). Global quality of life in mastocytosis was moderately positively correlated with anxiety ( $r$ o $=0.44 ; p<0.01$ ), depression ( $r$ o $=0.35 ; p<0.01)$, and irritability $(r h o=0.34 ; p<0.01)$ as 
Natalia Spolak-Bobryk, Marek Niedoszytko, Ewa Jassem, Marta Chełmińska, Magdalena Lange, Mikołaj Majkowicz, Bogusław Nedoszytko, Judyta Borchet

Table 4. Patient characteristics by gender

\begin{tabular}{lcc}
\hline Parameter & Men & Women \\
\hline$N(\%)$ & $28(33)$ & $57(67)$ \\
\hline Age & $M=45.32 ; \mathrm{SD}=10.80$ & $M=46.67 ; \mathrm{SD}=14.16$ \\
\hline Diagnosis of mastocytosis & Cutaneous mastocytosis (CM) $19(22.4 \%)$ & Systemic mastocytosis (SM) \\
& & $66(77.6 \%)$ \\
\hline Diagnosis of mastocytosis by gender & Women 14 (24.6\%) & Women 43 (75.4\%) \\
& Men 5 (17.9\%) & Men 23 (82.1\%) \\
\hline
\end{tabular}

Table 5. Frequency of clinical symptoms in the study group $(n=85)$

\begin{tabular}{|c|c|c|c|c|c|c|}
\hline Symptom & \multicolumn{4}{|c|}{ No } & \multicolumn{2}{|c|}{ No data } \\
\hline Allergy & \multicolumn{4}{|c|}{36} & \multicolumn{2}{|c|}{5} \\
\hline GI tract symptoms & \multicolumn{4}{|c|}{56} & \multicolumn{2}{|c|}{4} \\
\hline Osteopenia/osteoporosis (symptoms) & \multicolumn{4}{|c|}{48} & \multicolumn{2}{|c|}{18} \\
\hline Constitutional/cardiovascular & \multicolumn{4}{|c|}{67} & \multicolumn{2}{|c|}{2} \\
\hline Weight loss ( $\geq 10 \%$ within last 12 months) & \multicolumn{4}{|c|}{82} & \multicolumn{2}{|c|}{0} \\
\hline Malabsorption & \multicolumn{4}{|c|}{84} & \multicolumn{2}{|c|}{1} \\
\hline Portal hypertension & \multicolumn{4}{|c|}{85} & \multicolumn{2}{|c|}{0} \\
\hline Ascites & \multicolumn{4}{|c|}{85} & \multicolumn{2}{|c|}{0} \\
\hline Dysmyelopoiesis & \multicolumn{4}{|c|}{85} & \multicolumn{2}{|c|}{0} \\
\hline Spleen (palpable) & \multicolumn{4}{|c|}{83} & \multicolumn{2}{|c|}{1} \\
\hline Hepatomegaly (palpable) & \multicolumn{4}{|c|}{81} & \multicolumn{2}{|c|}{1} \\
\hline Lymphadenopathy (palpable or $>2 \mathrm{~cm}$ in US/CT) & \multicolumn{4}{|c|}{84} & \multicolumn{2}{|c|}{1} \\
\hline Symptom & $\begin{array}{c}\text { No } \\
\text { symptom }\end{array}$ & $\begin{array}{c}\text { Mild \& } \\
\text { infrequent }\end{array}$ & $\begin{array}{c}\text { Mild or moderate \& } \\
\text { frequent }\end{array}$ & $\begin{array}{l}\text { Severe \& } \\
\text { frequent }\end{array}$ & $\begin{array}{c}\text { Severe } \\
\text { adverse } \\
\text { event }\end{array}$ & No data \\
\hline Hypotension & 1 & 7 & 6 & 1 & 1 & 69 \\
\hline Flushing & 15 & 19 & 30 & 4 & 0 & 17 \\
\hline Pruritus & 7 & 18 & 40 & 3 & 0 & 17 \\
\hline
\end{tabular}

well as moderately negatively correlated with satisfaction with current life (rho $=-0.39 ; p<0.01$ ) and life in the next 4 weeks $(r h o=-0.38 ; p<0.01)$.

The analysis of rho-Spearman correlation between the studied variables and the 4 areas of the quality of life in mastocytosis revealed that (1) the more limitations in leisure time the participants encountered, the more anxiety ( $r$ o $=0.46 ; p<0.01$ ), depression ( $r$ o $=0.35 ; p<$ 0.01 ), and irritability (rho $=0.29 ; p<0.01$ ) as well as the less satisfaction with the current life (rho $=-0.34 ; p<$ 0.01 ) and life in the next 4 weeks ( $r$ o $=-0.36 ; p<0.01$ ) they experienced; (2) the more limitations related to protective behaviours the participants encountered in their lives, the more anxiety (rho $=0.23 ; p<0.05)$ and the less satisfaction with the current life (rho $=-0.40 ; p<0.01$ ) and life in next 4 weeks they experienced ( $r h o=-0.27$; $p<0.05)$. Interestingly, protective behaviours were not related to depression and irritability; (3) the more limitations in professional life the participants encountered, the more anxiety (rho $=0.41 ; p<0.01$ ), depression (rho
$=0.31 ; p<0.01)$, and irritability (rho $=0.33 ; p<0.01)$ as well as the less satisfaction with the current life (rho = $-0.31 ; p<0.01)$ and life in the next 4 weeks they experienced ( $r$ o $=-0.35 ; p<0.01$ ); (4) the more limitations in everyday life the participants encountered, the more anxiety (rho $=0.47 ; p<0.01$ ), depression ( $r h o=0.39$; $p<0.01$ ), and irritability (rho $=0.33 ; p<0.01$ ) as well as the less satisfaction with the current life (rho $=-0.31$; $p<0.01)$ and life in the next 4 weeks they experienced (rho $=-0.33 ; p<0.01$ ).

Participants' age was not related to either the QLMS' global quality of life in mastocytosis score or to its subscales. The correlations between the psychological variables, age, and QLMS scores are presented in Table 7.

\section{Discussion}

The results of our study indicated the importance of allergic symptoms and limitations in leisure time, which decrease quality of life. Firstly, among the clinical symptoms that oc- 
Table 6. The differences in QLMS dimensions by clinical symptoms occurrence

\begin{tabular}{|c|c|c|c|}
\hline Symptom & $\begin{array}{c}\text { Mean rank - symptom } \\
\text { present }\end{array}$ & $\begin{array}{c}\text { Mean rank - symptom } \\
\text { not present }\end{array}$ & $\begin{array}{l}U \text {-Mann Whitney test } \\
\text { of group differences }\end{array}$ \\
\hline \multicolumn{4}{|l|}{ QLMS - leisure time: } \\
\hline Allergy & 45.73 & 34.11 & $-2.29 ; p<0.05$ \\
\hline Gl tract symptoms & 39.00 & 41.89 & $-0.52 ;$ n.s. \\
\hline Osteopenia/osteoporosis (symptoms) & 34.34 & 33.86 & $-0.09 ;$ n.s. \\
\hline Constitutional/cardiovascular & 47.69 & 40.64 & $-1.08 ;$ n.s. \\
\hline Weight loss ( $\geq 10 \%$ within last 12 months) & 38.17 & 43.18 & $-0.36 ;$ n.s. \\
\hline Hepatomegaly (palpable) & 62.33 & 41.77 & $-1.48 ;$ n.s. \\
\hline \multicolumn{4}{|l|}{ QLMS - protective behaviours: } \\
\hline Allergy & 44.56 & 35.54 & $-1.81 ;$ n.s. \\
\hline Gl tract symptoms & 38.38 & 42.17 & $-0.71 ;$ n.s. \\
\hline Osteopenia/osteoporosis (symptoms) & 33.63 & 34.15 & $-0.10 ;$ n.s. \\
\hline Constitutional/cardiovascular & 41.63 & 42.09 & $-0.07 ;$ n.s. \\
\hline Weight loss ( $\geq 10 \%$ within last 12 months) & 38.67 & 43.16 & $-0.33 ;$ n.s. \\
\hline Hepatomegaly (palpable) & 37.17 & 42.70 & $-0.41 ;$ n.s. \\
\hline \multicolumn{4}{|l|}{ QLMS - professional life: } \\
\hline Allergy & 41.74 & 38.99 & $-0.56 ;$ n.s. \\
\hline Gl tract symptoms & 40.04 & 41.43 & $-0.26 ;$ n.s. \\
\hline Osteopenia/osteoporosis (symptoms) & 32.97 & 34.41 & $-0.29 ;$ n.s. \\
\hline Constitutional/cardiovascular & 38.38 & 42.87 & $-0.72 ;$ n.s. \\
\hline Weight loss ( $\geq 10 \%$ within last 12 months) & 51.67 & 42.68 & $-0.66 ;$ n.s. \\
\hline Hepatomegaly (palpable) & 48.00 & 42.30 & $-0.43 ;$ n.s. \\
\hline \multicolumn{4}{|l|}{ QLMS - life limitations: } \\
\hline Allergy & 41.24 & 39.60 & $-0.32 ;$ n.s. \\
\hline Gl tract symptoms & 41.96 & 40.57 & $-0.25 ;$ n.s. \\
\hline Osteopenia/osteoporosis (symptoms) & 34.24 & 33.91 & $-0.06 ;$ n.s. \\
\hline Constitutional/cardiovascular & 41.13 & 42.21 & $-0.16 ;$ n.s. \\
\hline Weight loss ( $\geq 10 \%$ within last 12 months) & 41.83 & 43.04 & $-0.09 ;$ n.s. \\
\hline Hepatomegaly (palpable) & 42.33 & 42.51 & $-0.01 ;$ n.s. \\
\hline \multicolumn{4}{|l|}{ QLMS - Global quality of life in mastocytosis: } \\
\hline Allergy & 43.39 & 36.97 & $-1.23 ;$ n.s. \\
\hline GI tract symptoms & 40.68 & 41.14 & $-0.08 ;$ n.s. \\
\hline Osteopenia/osteoporosis (symptoms) & 34.03 & 33.99 & $-0.01 ;$ n.s. \\
\hline Constitutional/cardiovascular & 42.22 & 41.95 & $-0.04 ;$ n.s. \\
\hline Weight loss ( $\geq 10 \%$ within last 12 months) & 41.83 & 43.04 & $-0.30 ;$ n.s. \\
\hline Hepatomegaly (palpable) & 50.33 & 42.21 & $-0.57 ;$ n.s. \\
\hline
\end{tabular}

curred in the studied group, which were allergy, Gl tract symptoms, osteopenia/osteoporosis symptoms, constitutional/cardiovascular symptoms, weight loss, and hepatomegaly, only symptoms of allergy analysed by our questionnaire differentiated between the patients in terms of their quality of life, and it was in the area of leisure time. Patients experiencing allergy symptoms presented lower QoL in the area of leisure time. This symptom prevents them from, for instance, going on holiday, traveling, visiting friends and family, and enjoying themselves outdoors (e.g., when walking or gardening).

A possible reason for the anxiety reported by the studied patients could be the fear of experiencing allergic symptoms in a place where professional medical assistance was not available. For example, if an anaphy- 
Natalia Spolak-Bobryk, Marek Niedoszytko, Ewa Jassem, Marta Chełmińska, Magdalena Lange, Mikołaj Majkowicz, Bogusław Nedoszytko, Judyta Borchet

Table 7. Rho-Spearman correlations between QLMS subscales and age, anxiety, depression, satisfaction with current life, and satisfaction with life in 4 weeks $(n=85)$

\begin{tabular}{|c|c|c|c|c|c|c|}
\hline Variable & Age & $\begin{array}{l}\text { HADS-M } \\
\text { Anxiety }\end{array}$ & $\begin{array}{c}\text { HADS-M } \\
\text { Depression }\end{array}$ & $\begin{array}{l}\text { HADS-M } \\
\text { Irritability }\end{array}$ & $\begin{array}{l}\text { Satisfaction with } \\
\text { life - today }\end{array}$ & $\begin{array}{l}\text { Satisfaction with life } \\
\text { - next } 4 \text { weeks }\end{array}$ \\
\hline QLMS - leisure time & 0.17 & $0.46^{\star \star}$ & $0.35^{\star \star}$ & $0.29^{\star *}$ & $-0.34^{\star \star}$ & $-0.36^{\star \star}$ \\
\hline QLMS - protective behaviours & 0.14 & $0.23^{*}$ & 0.18 & 0.21 & $-0.40^{* *}$ & $-0.27^{\star}$ \\
\hline QLMS - professional life & 0.17 & $0.41^{\star *}$ & $0.31^{\star *}$ & $0.33^{\star *}$ & $-0.31^{\star \star}$ & $-0.35^{\star *}$ \\
\hline QLMS - life limitations & 0.08 & $0.47^{\star *}$ & $0.39^{\star *}$ & $0.33^{* *}$ & $-0.31^{\star \star}$ & $-0.33^{\star *}$ \\
\hline QLMS - global quality of life in mastocytosis & 0.18 & $0.44^{\star *}$ & $0.35^{\star \star}$ & $0.34^{\star \star}$ & $-0.39^{\star *}$ & $-0.38^{\star *}$ \\
\hline
\end{tabular}

${ }^{*} p<0.05 ;{ }^{* *} p<0.01$.

lactic reaction occurs while being on holiday, the patient will not receive timely and effective medical assistance, or the patient's medical condition may not be known to local doctors. Such fears and the associated anxiety, as well as reduced quality of life are closely related to the risk of vacation sickness described by Reisinger and Mavondo. In their publication, the authors detail previous research on the above topic [24], mentioning, for example, the research conducted by Maser and Weiermair, which addressed not only the risk of illness, but also the risk of hygiene problems or cultural and language barriers during travel [25]. Research on tourism risk was also conducted by Roehl and Fesenmaier - they identified three dimensions of perceived risk: physical-equipment risk, destination risk, and vacation risk. Among the vacation risk elements, the authors list physical risk possibility that a trip to this destination will result in physical danger, injury, or sickness while on vacation [26]. Inferring from the studies reported in the literature above, people with rare diseases may experience anxiety and strong fear, together with insecurity related to uncertainty about the competence of foreign medical care.

When outdoors, anxiety may be associated with the risk of anaphylactic reactions to e.g., venoms of hymenopterous insects. A sting usually causes local erythema and swelling combined with a painful reaction, but a person who is allergic to venom may develop severe local reactions and symptoms leading to anaphylactic shock. A feeling of severe anxiety is a reaction triggered by a sting and is usually associated with the first-time lifethreatening condition. The occurrence of severe systemic symptoms in the patient, with particular emphasis on those affecting the respiratory system, usually results in a significant increase in the anxiety associated with the next sting and affects the quality of life [27].

An important issue is the presence of a high risk of recurrence of anaphylaxis among patients characterized by the most severe reactions - this is around $70 \%$ in subsequent years [28, 29]. Anaphylaxis, due to limitations in daily activities, affects both the physical and the psychological and social sphere of life - it is strongly related to conscious avoidance strategies (prevention of a repeated sting, presence of fear in contact with insects) [30, 31]. In the Department of Allergology of the Medical University of Gdansk, a study was carried out between 2003 and 2005 on a group of 71 patients diagnosed with clinically significant allergy to wasp venom and bee venom. The research stemmed from the need to measure quality of life, particularly in patients with insect venom allergy, and ultimately led to the development of the Polish version [32] of the Vespid Allergy Quality of Life Questionnaire (VQLQ) (for the original scale see: 30 ). The HADS questionnaire was among the materials that the patients were expected to complete. The results indicated that a high score (above 11), which indicated depression (HADS-D), was present in $10 \%$ of the patients, and high anxiety (HADS-A) was found in 33\% of the subjects. At the same time, it was noted that high anxiety was more common in women: 18 (40\%) than in men 5 (19\%) [32].

In her publication, Matysiak explains that the main principle of allergy prevention is to avoid the allergen, which in this particular situation amounts to the prevention of stings. Any person with a positive history of anaphylaxis should avoid walking in orchards and near apiaries or insect nests, especially on hot and humid days when insects are particularly irritated. It is also important to avoid clothing and perfume that attract insects, walking barefoot and eating and drinking outdoors. The recommendations also include a subsection on limiting outdoor sporting activities and information that generally available insect repellents are not effective in preventing stings. The recommendations also refer to the instructions in case of an insect attack, where special importance is given to staying calm and avoiding sudden and nervous movements [27, 33, 34]. Taken together, we think that informing the patients how they could prepare themselves to engage in these activities safely could improve their QoL in the area of leisure time.

Anxiety is a common emotional state, a natural reaction to diseases, and a consequence of the sense of threat. In the studied group of patients with mastocytosis, anxiety was observed in $27.1 \%$ of the subjects. Additionally, signs of depression were found in $12.9 \%$ of the patients. Thus, in the studied population, anxiety was more prevalent than depression. The assessment was performed using the HADS-M questionnaire, a measure 
successfully used in studying patients with various conditions. For instance, it was used in a study by Lin and Pakpour, involving 1041 patients with epilepsy. The HADS showed that $55.3 \%$ of those participants had anxiety; $56.0 \%$ had depression, based on its cut-offs [35]. Wichowicz and Wieczorek used HADS in screening tests for depression and anxiety disorders in patients following ischaemic brain stroke. The study group comprised the patients of the Department of Neurology with a history of a single ischaemic brain stroke. HADS proved to be a useful scale in the screening for depression and anxiety disorders in patients after a brain stroke [36].

The dissatisfaction with current life was assessed by $15.3 \%$ of patients with mastocytosis. $10.6 \%$ assessed their satisfaction with their lives in the next 4 weeks as low. This assessment was based on the scores of the Cantril Ladder, a measure successfully used in studying patients with various conditions. For example, Sutkowski et al. used it in a study on satisfaction with life in patients undergoing dialysis. The results indicated highly positive relationships between high expected 5-year Cantril Ladder-satisfaction with life scores and being in a relationship, having a kidney graft performed in the past, and willingness to have a kidney graft performed in the future [37]. The Cantril Ladder was also used in a study by Cepuch. Its aim was to assess the degree of pain and the level of activity and disease acceptance in a group of 50 subjects, aged 14-18 years, with juvenile idiopathic arthritis (JIA) in remission. Apart from Cantril Ladder, this study used the numerical scale (NRS 0 - 10), the author's own activity scale, and the Acceptance of Illness Scale (AIS). A high correlation was observed between the acceptance of the disease determined with the use of Cantril Ladder and AIS at the moment of the test [38].

General QoL in mastocytosis, as well as the four areas of QoL in mastocytosis (leisure time, protective behaviours, professional life, and life limitations), generally remained moderately positively correlated with anxiety, depression, and irritability as well as negatively correlated with satisfaction with current life and life in the next 4 weeks. The obtained results are consistent with the investigations by Urbańska, who emphasizes the importance of daily life in the ecosystem when the reality in which a person functions forces them to be active in constantly changing conditions. The sense of obligation to meet expectations and fulfil tasks related to one's social position, including family, everyday life, health, and work functions, has a profound impact on the occurrence of psychophysical imbalance and may result in intense fatigue, both psychological (lack of security, autonomy, unmet needs), physical (lack of rest) and social (overload with interactions), which, in turn, is linked to anxiety, depression, irritability, and low satisfaction with life [39].

As our study was correlational, we cannot infer the causality in these relations. However, we know that the anxiety experienced by mastocytosis patients may be associated with the sense of threat to life, suffering from the disease symptoms, and undergoing diagnostic and therapeutic procedures [17]. Therefore, we believe that educating the patients on their condition and the factors that may lead to the exacerbation of mastocytosis symptoms (e.g., exposure to sudden temperature changes, certain foods, pungent spices, certain medications, sunlight, alcohol, insect venoms, stress, or infections) could increase their sense of safety and decrease the anxiety and thus have a positive impact on their quality of life. This idea seems to be in line with the fact that in our sample, the levels of depression and irritability did not remain statistically significantly correlated with the level of protective behaviours the patients undertake. It is possible that the study participants knew the benefits of protective actions thus were not irritated or depressed because of them. Having more obstacles in various areas of life (work, leisure time, everyday life, and the need to perform many protective behaviours) is linked to anxiety, depression, irritability, and low satisfaction with life. Learning how to overcome them can potentially improve the patients' quality of life.

\section{Acknowledgments}

This work is a result of collaboration between the patients of the Department of Allergology, Medical University of Gdansk, Poland, and the medical personnel psychologists and physicians. We would like to recognize their participation.

The study was supported by one of the authors' scholarship - Natalia Spolak-Bobryk was awarded with a Santander Universidades Scholarship (29/2020).

\section{Conflict of interest}

The authors declare no conflict of interest.

\section{References}

1. Le M, Miedzybrodzki B, Olynych T, et al. Natural history and treatment of cutaneous and systemic mastocytosis. Postgraduate Medicine 2017; 129: 896-901.

2. Brockow K. Epidemiology, prognosis, and risk factors in mastocytosis. Immunol Allergy Clin North Am 2014; 34: 283-95.

3. Valent P, Akin C, Hartmann K, et al. Advances in the classification and treatment of mastocytosis: current status and outlook toward the future. Cancer Res 2017; 77: 1261-70.

4. Valent P, Akin C, Metcalfe D.D. Mastocytosis: 2016 updated WHO classification and novel emerging treatment concepts. Blood 2017; 129: 1420-7.

5. Lange M, Flisiak I, Kapińska-Mrowiecka ML, et al. Mastocytosis. Diagnostic and therapeutic recommendations of the Polish Dermatological Society. Dermatol Rev 2018; 105: 358-83.

6. Hartmann K, Escribano L, Grattan C, et al. Cutaneous manifestations in patients with mastocytosis: consensus report of the European Competence Network on Mastocytosis; the American Academy of Allergy, Asthma \& Immunology; and 
the European Academy of Allergology and Clinical Immunology. J Allergy Clin Immunol 2016; 137: 35-45.

7. Lange M, Ługowska-Umer H, Niedoszytko M, et al. Diagnosis of mastocytosis in children and adults in daily clinical practice. Acta Derm Venereol 2016; 96: 292-7.

8. Pardanani A. Systemic mastocytosis in adults: 2017 update on diagnosis, risk stratification, and management. Am J Hematol 2016; 91: 1146-59.

9. Valent P, Escribano L, Broesby-Olsen S, et al. Proposed diagnostic algorithm for patients with suspected mastocytosis: a proposal of the European Competence Network on Mastocytosis. Allergy 2014; 69: 1267-74.

10. Broesby-Olsen S, Dybedal I, Gülen T, et al. Multidisciplinary management of mastocytosis: nordic expert group consensus. Acta Derm Venereol 2016; 96: 602-12.

11. Scherber RM, Borate U. How we diagnose and treat systemic mastocytosis in adults. Br J Haematol 2018; 180: 11-23.

12. Siebenhaar F, Akin C, Bindslev-Jensen C, et al. Treatment strategies in mastocytosis. Immunol Allergy Clin North Am 2014; 34: 433-47.

13. Güllen T, Akin C. Pharmacotherapy of mast cell disorders. Curr Opin Allergy Clin Immunol 2017; 17: 295-303.

14. Niedoszytko M, Jassem E, Kruszewski J. Mastocytoza - rozpoznanie i leczenie. [Diagnosis and treatment of mastocytosis]. Wydawnictwo Benkowski, Białystok, Poland 2007.

15. Jennings S, Russell N, Jennings B, et al. The Mastocytosis Society Survey on Mast Cell Disorders: patient experiences and perceptions. J Allergy Clin Immun 2014; 1: 70-6.

16. Castells M, Austen KF. Mastocytosis: mediator-related signs and symptoms. Int Arch Allergy Immunol 2002; 127: 147-52.

17. Hermine O, Lortholary O, Leventhal PS, et al. Case-control cohort study of patients' perceptions of disability in mastocytosis. PLOS One 2008; 5: 1-14.

18. Majkowicz M. Praktyczna ocena efektywności opieki paliatywnej - wybrane 133 techniki badawcze. [Practical assessment of the effectiveness of palliative care -133 selected research techniques]. In: Ocena jakości opieki paliatywnej $w$ teorii i praktyce. [Assessment of the quality of palliative care in theory and in practice]. de Walden-Gałuszko K, Majkowicz M (eds.). Medical University of Gdańsk, Gdańsk, Poland 2000; 21-42.

19. Zigmond AS, Snaith RP. the hospital anxiety and depression scale. Acta Psych Scand 1983; 67: 361-70.

20. Mazur J, Woynarowska B, Kołoło H. Zdrowie subiektywne, styl życia i środowisko psychospołeczne młodzieży szkolnej w Polsce. Raport techniczny z badań HBSC 2006. [Subjective health, lifestyle and psychosocial environment of school-age children in Poland. A Technical report regarding 2006 HBSC studies] IMiD. Warsaw, Poland 2007.

21. Spolak-Bobryk N, Niedoszytko M, Jassem E, et al. Assessing Quality of Life in Patients with Mastocytosis - development of the disease-specific questionnaire. Adv Dermatol Allergol 2021; 38(6). DOI: https://doi.org/10.5114/ada.2021.108435.

22. Mann HB, Whitney DR. On a test of whether one of two random variables is stochastically larger. Annf Mathemat Stat 1947; 18: 50-60.

23. Bedyńska S, Cypryańska M. Statystyczny Drogowskaz 1. Praktyczne wprowadzenie do wnioskowania statystycznego. Wydawnictwo Akademickie Sedno, Warszawa, Poland 2013.

24. Reisinger Y, Mavondo F. Travel anxiety and intentions to travel internationally: implications of travel risk perception. J Travel Res 2005; 43: 212-25.
25. Maser B, Weiermair K. Travel decision-making: from the vintage point of perceived risk and information preferences. J Travel Tourism Marketing 1998; 7: 107-21.

26. Roehl W, Fesenmaier D. Risk perceptions and pleasure travel: an exploratory analysis. J Travel Res 1992; 30: 17-26.

27. Matysiak J, Matysiak J, Kokot ZJ, et al. Alergia na jad owadów błonkoskrzydłych ze szczególnym uwzględnieniem pszczoły miodnej (Apis mellifera) - aktualny stan wiedzy. Alergia Astma Immunol 2011; 16: 163-71.

28. Bonifazi F, Jutel M, Bilo B, et al. Prevention and treatment of hymenoptera venom allergy: guidelines for clinical practice. Allergy 2005; 60: 1459-70.

29. Biló B, Rueff F, Mosbech H, et al. Diagnosis of Hymenoptera venom allergy. Allergy 2005; 60: 1339-49.

30. Oude Elberink J, de Monchy J, Golden D, et al. Development and validation of a health-related quality-of-life questionnaire in patients with yellow jacket allergy. J Allergy Clin Immunol 2002; 109: 162-70.

31. Oude Elberink J, De Monchy J, Van Der Heide S, et al. Venom immunotherapy improves health-related quality of life in patients allergic to yellow jacket venom. J Allergy Clin Immunol 2002; 110: 174-82.

32. Niedoszytko M, Majkowicz M, Chełmińska M, et al. Quality of life, anxiety, depression and satisfaction with life in patients treated with insect venom immunotherapy. Adv Dermatol Allergol 2012; 29: 74-9.

33. Greene A, Breisch NL. Avoidance of bee and wasp stings: an entomological perspective. Curr Opin Allergy Clin Immunol 2005; 5: 337-41.

34. American Academy of Allergy, Asthma, and Immunology, Public Education Comittee. Tips to remember. Available online: https://ohioallergyclinic.com/wp-content/uploads/ pdfs/Patients\&Consumers_Center_\%20Tips_to_Remember_Outdoor_allergens.pdf

35. Lin CY, Pakpour AH. Using Hospital Anxiety and Depression Scale (HADS) on patients with epilepsy: confirmatory factor analysis and Rasch models. Seizure 2017; 45: 42-6.

36. Wichowicz HM, Wieczorek D. Badanie przesiewowe depresji poudarowej z użyciem Hospital Anxiety Depression Scale (HADS). [Screening for post-stroke depression with the use of Hospital Anxiety Depression Scale (HADS)]. Psychiatr Pol 2011; 36: 505-14.

37. Sulkowski L, Matyja M, Walocha JA, et al. Satisfaction with life among dialyzed patients: a cantril ladder survey. MGM J Med Sci 2018; 5: 6-11.

38. Cepuch G, Tomaszek L, Trybek-Bronowicz M. Pain intensity in patients with juvenile idiopathic arthritis and the level of their activity and the disease acceptance. Reumatologia 2014; 52: 299-304.

39. Urbańska J. Zmęczenie życiem codziennym. Środowiskowe i zdrowotne uwarunkowania oraz możliwości redukcji w sanatorium. Wydawnictwo Naukowe Wydziału Nauk Społecznych Uniwersytetu im. Adama Mickiewicza. Poznań, Polska 2010. 